\title{
Understanding Attitudes towards Gasoline Import Demand in Viet Nam
}

\author{
Hoang Thi Lan Huong \\ School of Economics, Shanghai University
}

\begin{abstract}
Even with its vast reserves of oil and gas potential, the government has put this fuel resource the top of priority sectors for development, as it views as central to national economic growth as well as energy security, Viet Nam has remained a net importer of petroleum products over the past eight years. On another word, Gasoline importation has been a superior absorbability on the economy of Viet Nam, the determinants of the refined oil products imported activities analysis have been found no study yet. This paper aims to suggest the leading factors affecting import demand performances for petroleum products. The autoregressive distributed lag modelling framework (ARDL) have applied to this research; we estimated various short-run and long-run import demand models for Gasoline using time series study over the period 1995-2015. The results showed that the application of gas is stable prices in both the long and short term. Other principal operators of gas import probably are the real effective exchange rate, domestic petroleum production, and population growth. Moreover, a real economic activity found the most active and influential driver of gasoline demand accordance with the inelastic and elastic coefficients estimated in the short-run and long-run, respectively.
\end{abstract}

Keywords: Gasoline demand, import, determinants, co-integration, Viet Nam

\section{Introduction}

Crude oil and gas have played an important role throughout world history, nowadays, it is driving the expansion of the global businesses, manufacturing, goods and services transportation, and maritime trade at the national. Globalisation itself offers the significant potential to raise economic growth rates. The inquiry of higher growth rates implies the commitments to a sufficient supply of crude oil, and its core products such as gasoline, liquefied petroleum gas (LPG), kerosene amongst others for not only the domestic and industrial but also for the agricultural as well as transport sectors of any economy. The connection between the crude oil price and the petroleum product price, the demand and supply are key factors analysis of the refined industry that transforms crude oil as a raw material in a set of final products for the end consumers. Understanding the dynamics of the petroleum sub-sector and demand for petroleum product gasoline is very critical for policy aspirations in Viet Nam.

Viet Nam has risen from one of the poorest regions of Asia to a middle-income country. The GDP in Viet Nam reported to expanding 6.40 percent in the September quarter of 2016. GDP Growth Rate in Viet Nam averaged 6.16 percent from 2000 until 2016. Thus, the rate reached its highest record 8.46 in the last quarter of the year 2017 and to its lowest record 3.14 percent by the first three months of the year 2009. The productions of goods and services in various sectors are because of the rapid growth of the economy, having a significant effect on energy consumption of petroleum products, especially, and gasoline. Mr Angus Mitchell, the partner at DFDL and head of the firm's oil and gas division, stated, "Though it remains a net exporter of crude oil, Viet Nam is a net importer of refined petroleum products." In another word, despite its relatively little oil import and oil resource dependence, as a small and open economy, it is nevertheless not only a net oil importer, but also has the transportation system highly determined by liquid fuels, and is, therefore, vulnerable to oil price shocks. Total domestic refined oil products consumption continues to rise while production had remained largely constant from 2010 until 2012. The petroleum subsector within the entire energy sector faces an oversight responsibility for deregulation, regulated by the Ministry of Foreign Affairs. The data for Viet Nam from 1986 to 2012 provided by the U.S. Energy Information Administration. The average value for Viet Nam during that period was 44.5 thousand barrels per day with a minimum 6.54 thousand barrels per day in 1986 and a maximum of 117.64 thousand barrels per day in 2012 (EIA, 2013). To satisfy its domestic demand, Viet Nam must import a majority of refined products from Singapore, Korea, as well as China. Despite the fact that Viet Nam exported USD 8.2 billion of crude oil in 2012, a lack of domestic refining capacity also means that Viet Nam remains a price-taker in international markets for petroleum products. It explains why fluctuation of oil prices in international market trends threatens the stability of oil price in Viet Nam's domestic market.World crude oil prices fluctuate with changes in the local market, which results from the use of automatic price adjustment formula for pricing petroleum products. One of the largest price stabilisation efforts ever undertaken was the refined oil price stabilisation fund established by the Vietnamese government to control the domestic market. It considered as the strongest financial strategy to avoid a sudden increase in prices of petroleum 
products to ensure inflation control and macro economy stability. At the accumulated level, gasoline comprises a significant share of total imports and a major contributor to the worsening trade balance and the overall balance of payment (BOP) position. Gasoline imports have risen from US\$1.857 billion in 1985 to US\$ 15.470 billion in 2015. The massive petroleum products import bill continues to be a culvert on the foreign reserve and BOP of the economy. The direct and indirect impacts on other economic sectors cannot overemphasise. International Monetary Fund's forecast shows that Viet Nam's status as a petroleum products net importer. Viet Nam's fossil import dependency has been expected to increase shortly because of limited domestic coal and gas resources, as an oil exporting country, the end to or downsizing of thirst for petroleum products importation is not in sight, at least in the medium term. It estimated that Viet Nam would likely maintain a crude oil output of approximately 340,000 barrels per day in the next several years, rank 36th in the world in the term of exploitation scale and the fourth in Southeast Asia in the length of oil exports. Imports are from mainly from Singapore at 37.2 percent, then China at 14.6 percent and Taiwan at $14.2 \%$ according to the General Department of Viet Nam Customs Statistic.

The elasticity demand for gasoline import has extensively studied over the last 40 years at the national, regional and global. Their empirical studies of gasoline demand have adopted a variety of different estimation strategies. However, no study has been conducted that estimated income and price elasticity among other indicators to explain gasoline import demand behaviour despite the importance of gasoline import in the economy of Viet Nam. The article offers researchers a thoughtful interpretation of the literature since it is the very first study to bring in advance the issues regarding Viet Nam's import demand for Gasoline. The autoregressive distributed lag model (ARDL) has applied to empirically estimate both short-run and long-run price and income elasticity of Gasoline import of Viet Nam. Other relevant variables such as the real effective exchange rate (REER), domestic gasoline production and population growth rate has been conducted. The structure of the paper is as follows. Section 2 lays the conceptual foundation by considering the role of global gasoline prices in the modern industrial economy via some previous studies. Data issues and the econometric approach are discussed in Section 3, while the analysis of the empirical results presented in Section 4. The paper terminates with some policy implications in Section 5.

\section{Literature Review}

This piece of research carries out a meta-analysis with a procedure suggested by George Marbuah (2014) using the methodology of the autoregressive distributed lag modelling framework (ARDL) to approximate calculation crude oil import demand in the Ghana market. His paper estimated that "variant shortrun and long-run import demand models for crude oil using time series data over the period 1980-2012. The results show that demand for crude oil is price inelastic in both the long and short term. Other important drivers of crude oil import are the real effective exchange rate, domestic crude oil production, and population growth". He additionally found that the GDP plays an important role along with domestic oil production in determining oil imports. He "identified oil, GDP, population growth and share of the industrial sector in GDP as the drivers of crude oil demand."

Although numerous papers have provided an appraisal of the price elasticity of demand for gasoline, in particular, Adeolu O. Adewuyi (2016), examined that "Determinants of import demand for refined petroleum products in Nigeria for the period 1984-2013". It employed the autoregressive distributed lag (ARDL) bounds test co-integration method to analyse "both long-run and short-run determinants of import demand for total and specific petroleum products." He found "aggregate and sectoral incomes are significant determinants of import of refined kerosene" in the long-run relationship. He also considered that the "Real effective exchange rate (REER), aggregate income (GDP), manufacturing sector's income, domestic energy production (DEP) and population growth rate (PGR) are drivers of import of refined motor spirit Moreover, REER, DEP and manufacturing sector's income are propellers of import of refined distillate fuel. Also, REER and total output of petroleum products are major drivers of total import of refined petroleum products" (Adewuyi, 2016). Also, he believed that "Short-run results show that the previous period GDP, PGR and manufacturing and service sectors' incomes are determinants of import demand for refined kerosene. Moreover, REER, GDP, previous PGR and manufacturing industries' income exert significant effects on the import of pure motor spirit. Further, significant effects of REER, DEP, previous PGR, domestic output of the product and manufacturing and service sectors' incomes on the import demand for distillate fuel".

Regarding the price elasticity of gasoline demand, and revenue another study by Oludele A. Akinboade, Emmanuel Ziramba, and Wolassa L. Kumo 2008, likewise "using the developed Autoregressive Distributed Lag (ARDL) bound testing approach to co-integration" (Akinboade et all, 2008), they "empirically analyzed the long-run relationship among the variables in the aggregate gasoline demand function over the period 1978-2005". Their study "Evaluated price and income elasticities of -0.47 and 0.36 imply that gasoline demand in South Africa is price and income inelastic". 
The latest contribution to the literature of meta-price elasticities of gasoline demand in this paper is Seydina Ousmane Sene, 2012; he estimated "the aggregate demand for gasoline in Senegal from 1970 to 2008. The long-term and short-term elasticities of demand on gas prices and income are of paramount interest". He stated that in Senegal, rising food prices, unemployment, and a "shortage of electric supply are always associated with the spiking cost of world oil prices". He found that "short-run elasticity is smaller than long-run elasticity and gasoline demand is inelastic with respect to both price and income for both the short and long runs in Senegal." (Sene, 2012)

\section{Methodology}

We estimate the specified models using annual time series data for the period 1986-2015. All the information used in this paper sourced from the General Department of Viet Nam Customs database and World Economic Outlook of the IMF, World Development Indicators (WDI) of the World Bank, as well as the Energy Information Administration (EIA) of the US Department of Energy. The gross domestic price (GDP) and the gasoline price measured in US dollars at constant prices. All econometric estimation series converted into natural logarithm form. Applied the standard framework modelling for energy demands which suggested by the request theories for goods and services; compatible with the literature reviews, as a function of real income and the international price of gasoline, we formulated our original gasoline import demand model. Accordingly, the actual value of gasoline import is specified as a function of real GDP and the real price of oil for Viet Nam as follows:

$$
G M_{t}=f\left(G P_{t}, G D P_{t}\right)
$$

Where: GMt contributes the value of gasoline import in a million dollars; GDPt is the amount of real GDP in a million dollars. Gasoline price, GPt, is the average world price comprising of Vietnamese market in US dollars per barrel. It is deflated by the world consumer price index (CPI, 2005=100) to acquire the gasoline price in real terms. Equation (1) is expressed in logarithmic form as follows:

$$
\ln G M_{t}=\beta_{0}+\beta_{1} \ln G P_{t}+\beta_{2} \ln G D P_{t}+\varepsilon_{t}
$$

Where: all the variables are as previously defined excepted $\varepsilon_{t}$, an error term expected to satisfy all the residual regression assumptions of no serial correlation, homoscedasticity, normality and correct model specification. Since the model developed in logarithmic form, the estimated parameters represent elasticity. Standard demand theory posits a negative relationship between the quantity demanded and the price of a good. Therefore, we expected that a higher price of gasoline would reduce the amplitude of the application for petrol, ceteris paribus $\beta_{1}<0$. Conversely, higher income levels are expected to dismiss economic activities and higher demand for gasoline correspondingly. Thus, we assumed import demand for gasoline to respond positively to real income $\beta_{2}>0$. As an extension of the basic model (2), we included additional variables such as Viet Nam's real effective exchange rate (REER), domestic gasoline production (Gprd) and the rate of growth of population (POPG) as controls for other potential determinants of an aggregate gasoline import demand. We then estimated another model as:

$$
\ln G M_{t}=\alpha_{0}+\alpha_{1} \ln G P_{t}+\alpha_{2} \ln G D P_{t}+\alpha_{3} X_{t}+v_{t}
$$

All other variables except $\mathrm{Xt}$ which denote a vector of additional control variables such as REER, Gprd and POPG, and $v_{t}$ (error term) remain defined as previously. An alternative variable used in the literature in place of POPG is the urban growth rate of the country. In our case, two variables did not alter the results in any significant way. The inclusion of REER in the demand equation is necessary because the oil price on the world market quoted in US dollars. Further, any change in the exchange rate of the local currency against the US\$ affects the domestic price of oil and the real value of financial assets/wealth and hence the demand for oil. Since Viet Nam is a net importer of petroleum products and a price-taker, any changes in the exchange rate will affect demand for gasoline. The REER variable is defined such that an increase implies a real appreciation of Viet Nam's currency (VND) against the US\$. Therefore, real recognition of the local currency against the US\$ should stimulate aggregate demand and hence a higher demand for gasoline. Also, increased domestic petroleum productions could have a substitution effect for imported gasoline; hence, we expect it to have an adverse impact on gasoline import demand. Due to degrees of freedom reasons, other macroeconomic variables such as international/foreign reserves, interest rate among others excluded from the model.

This empirical study employs ARDL model which known as a unique approach with some more delicate benefits. "The major and pertinent beauty of this approach are in the fact that it can work efficiently irrespective of the scenario either data has a unit root or not" (Pesaran et el., 2001). "The hidden beauty of the ARDL approach is that one study short-run as well long-run relationships without losing any relevant information from data (Waliullah et el., .2010). To estimate the short-run and long-run determinants of gasoline import demand, we use the ARDL modelling approach by Pesaran et el. (2001). This model approach comprises 
estimating a dynamic model by incorporating the lags of the dependent variables as well as the lagged and contemporaneous values of the independent variables. The short-run components are then estimated directly while the long-run effects obtained indirectly. In this study, we utilise the bounds test for co-integration analysis within the ARDL framework. The most critical edge of ARDL over other co-integration procedures "The freedom from larger specifications like some endogenous and exogenous variables to be included, optimal lags number, a different number of optimal lags for different variables and model can work even for a short number of observations" (Duasa, 2007). Although "ARDL bounds testing to co-integration holds regardless of the order of integration of each series, we still formally test it to ensure that none of the series is I(2) or higher in which case the calculated F-statistic becomes invalid ( Ouattara, 2004).

We implement the ARDL approach in two main steps. As a precursor to estimating the short-run and long-run elasticities we first test for co-integration to ascertain whether there is any long-run equilibrium relationship among the variables in the model to be estimated. If the co-integration is established, we then determine the long-run coefficients and the associated short-run parameters via the ARDL framework. The ARDL framework for the equation (2) involves determining the following unrestricted error correction model (UECM):

$$
\begin{aligned}
& \Delta \ln G M_{t}=\lambda_{0}+\sum_{i=1}^{n} \lambda_{1} \Delta \ln G M_{t-i}+\sum_{i=0}^{n} \lambda_{2} \Delta \ln G P_{t-i}+\sum_{i=0}^{n} \lambda_{3} \Delta \ln G D P_{t-i}+\sum_{i=0}^{n} \lambda_{4} \Delta X_{t-i} \\
& +\eta_{1} \ln G M_{t-i}+\eta_{2} \ln G P_{t-i}+\eta_{3} \ln G D P_{t-i}+\eta_{4} X_{t-i}+\omega E C M_{t-i}+\mu_{t}
\end{aligned}
$$

Where: $\Delta$ are the difference operator and all other variables are as earlier defined and the terms $\lambda_{1}, \lambda_{2}, \lambda_{3}$ and $\lambda_{4}$ are the short-run coefficients while $\eta_{1}, \eta_{2}, \eta_{3}$ and $\eta_{4}$ denote the long-run elasticities. ECMt- 1 is the error correction term, which measures the speed of adjustment to long-run equilibrium following a shock to the system.

Co-integration among the variables confirmed within the bounds test framework by testing the collective null hypothesis that the coefficients of lagged level variables (Ouattara,2004), are significantly zero in the equation (4). That is the null hypothesis represented by $H_{0}=\eta_{1}=\eta_{2}=\eta_{3}=\eta_{4}=0$ is rejected; then the hypothesis is no co-integration might reject against the alternative $H_{1}: \eta_{1} \neq 0, \eta_{2} \neq 0, \eta_{3} \neq 0, \eta_{4} \neq 0$ of cointegration using either a Wald or an $F$-test. We use the $F$-test in this paper. This is an $F$-test with a nonstandard asymptotic distribution, which is dependent on whether the included variables in the ARDL model are either $I(0)$ or $I(1)$, number of regressors, whether an intercept and/or a trend included in the ARDL model, and the sample size (Pesaran et al. 2001; Ghosh, 2009). Pesaran et al. (2001) then provide two sets of critical values in testing for co-integration when the major variables are $I(1)$ or $I(0)$. If the calculated $F$-statistic exceeds the critical upper bound at some significance level, then we can safely reject the null hypothesis of no cointegration. Conversely, if the calculated $F$-statistics falls below the lower critical limit, we fail to reject the null of no co-integration. If it, however, falls within the band, then our inference is inconclusive. In either of the models to be estimated, null hypothesis denotes $F_{G M}($.$) .$

\section{Unit root results}

\section{Empirical Results}

The Phillips-Perron (PP) (1988) unit root tests for non-stationarity of the underlying time series, which is another serial correlation controlling method when it comes to a test for a unit root, have been applied for this study. The PP procedure tests the null hypothesis of a unit root contrary to the difference of stationarity of this series. The results presented in Table 1 include an intercept in the PP regression; the results indicated that all the variables contain a unit root. Stationarity, however, achieved after the first differencing of the variables. Therefore, we can conclude that all the variables integrated of orders; there is an indication of the possible longrun relationship among the variables.

Table 1: Phillips-Perron (PP) test results

\begin{tabular}{|lcl|}
\hline Variables & Level & First Difference \\
\hline & & $-6.720 * * *$ \\
\hline $\ln G M$ & 0.0835 & $-4.329 * * *$ \\
\hline $\ln G P$ & -1.0268 & $-3.433^{* *}$ \\
\hline $\ln G D P$ & 1.4763 & $-4.279^{* * *}$ \\
\hline $\ln R E E R$ & -0.5120 & $-3.808^{* *}$ \\
\hline $\ln G p r d$ & -0.2331 & $-5.670^{* * *}$ \\
\hline$P O P G$ & -1.8245 & \\
\hline
\end{tabular}

Note: $* * *, * *$ denote rejection of the null hypothesis of a unit root at the $1 \%$ and $5 \%$ levels, respectively. The test includes an intercept. The Critical values are base on MacKinnon (1996) one-sided. 


\section{Co-integration test results}

The result of the bounds test for co-integration relation demonstrates in Table 2. Co-integration has been tested using four different specifications. The results report the presence of a long-run relationship in the case where oil import demand modelled as a function of only gasoline price and real output. It clearly to be seen, the F-statistic 7.83 exceeds the upper critical bounds at both the 5\% and $10 \%$ levels. Thus, gasoline price and economic activities can be considered long-run drivers of gasoline demand in the model (1). The inclusion of additional variables also reveals a significant co-integration relationship between gasoline demand and gasoline price, real GDP and a combination of the real effective exchange rate, domestic gasoline production, and population growth. For that reason, we might conclude that global gasoline price, real output, a measure of Viet Nam's international competitiveness REER and the rate of population growth are long-run drivers of real petroleum products import demand in Viet Nam. Then, we proceed the long-run elasticities estimation and the associated error-correction models in the next section.

Table 2: Bounds test for co-integration

\begin{tabular}{|c|c|c|c|c|c|}
\hline Dependent variables & & \multicolumn{2}{|l|}{ F-statistics } & \multicolumn{2}{|c|}{ Critical bounds } \\
\hline & & & $5 \%$ & & $10 \%$ \\
\hline & & $I(0)$ & $I(1)$ & $I(0)$ & $I(1)$ \\
\hline$F_{G M}(G M \mid G P, G D P)$ & 7.83 & 3.1 & 3.87 & 2.63 & 3.25 \\
\hline$F_{G M}(G M \mid G P, G D P, R E E R, P O P G)$ & $9.21 * *$ & 2.56 & 3.49 & 2.2 & 3.09 \\
\hline$F_{G M}(G M \mid G P, G D P, R E E R, G P r d)$ & $8.23 * *$ & 2.56 & 3.49 & 2.2 & 3.09 \\
\hline$F_{G M}(G M \mid G P, G D P, R E E R, G P r d, P O P G)$ & $7.90 * *$ & 2.39 & 3.38 & 2.08 & 3 \\
\hline
\end{tabular}

\section{Estimated long-run and short-run results}

The results of the estimated long-run and short-run elasticities are described in Tables 3 and 4, respectively. As an ancestor to the estimated coefficients interpretation, we impose the appropriateness of our short-run model (or error correction model) for our analysis. The estimated coefficients of the error correction terms (ECMt-1) correctly signed (negative) and statistically significant. It implies that of the models can follow any shocks; long-run equilibrium would still attain or returned to through an adjustment process. Additionally, our results show that the real gasoline import demand explained largely by variations in its determinants with an $R^{2}$ widespread between 82 and 89 percent. Diagnostic tests employed on the residuals of the short-run model confirm that the models well functioned on serial correlations, correct functional form, normality, and constant variances. Last but not least, stability tests on the parameters assessed using Brown et al.' (1975) to the cumulative sum of recursive residuals (CUSUM), the aggregate sum of squares of residuals (CUSUMQ) included. In all the estimated models, both CUSUM and CUSUMQ tests indicated parameter stability in the ways that estimated statistics of each test falls within $5 \%$ critical bounds.

In the long-run relationship, real import demand for gasoline is less responsive to real international crude oil products price. It can clearly be seen, import demand for gasoline in Viet Nam is a price inelastic in both the long-run and short-run. As depicted in Table 3, there is a significant inverse relationship between gasoline price and gasoline import demand, suggested by models (2) and (3). The significances are consistent with demand theory, which posits a declining demand to higher prices of goods and services. Gasoline price is statistically not significant in models (1) and (4) although it is negative from the result. Markets are fluctuations where the changing in oil price significantly drive in response to the gasoline demand; we see that a $10 \%$ hike in oil price on the international commodities market would imply a depressing effect on the import demand for gasoline between $3.24 \%$ and $3.87 \%$ from models (2) and (4) respectively. The results are significant for both the current and the first period lagged estimates of international gasoline price for the model (1) to model (4). Correspondence to the long-run results, all the estimated coefficients of gasoline price are inelastic in the shortrun, ranging between $0.76-0.88$ for the current period price and $0.35-0.53$ in the case of a one-period lag in petroleum's price. The inelastic price estimates on import demand for gasoline implies that changes in prices do not have a big effect on the request for oil products in Viet Nam. Demanding for oil products may increase regardless of the world oil price, at least in the short-run. Not surprisingly, though, we find that the dominant driver of a high import demand for refined crude oil products in Viet Nam is the level of economic activities in both the long-run and short-run.

All the estimated coefficients of real economic activities in models (1) to (4) are positive and statistically significant at the $1 \%$ level. Accordingly, the demand for gasoline in Viet Nam is income elastic in the other period under consideration. The estimated elasticity of gasoline imports to revenue to the long-run implies that ceteris paribus, an increase in real income of the economy would stimulate real economic activities in energy-dependent sectors of the economy. For an instant, an increase in real GDP by one percentage point 
would increase gasoline imports by $3.41 \%, 5.16 \%, 5.66 \%$ and $3.04 \%$ in the long-run, shown by models (1) to (4). Viet Nam evidently rapid economic growth in recent years correspondingly associated with ballooning petroleum products import bills. The function of the real effective exchange rate in the determination of actual gasoline demand has reviewed in the literature. Concerning above reasons could be reasonable enough in explaining the effect of the REER variable in our real gasoline import demand patterns. For example, results in the long-run (models (2), (3) and (4) show that real appreciation of the Vietnamese currency against the US dollar stimulates demand for gasoline with an inelastic effect. In contrast, only the lags effect of the REER significantly influence the gasoline import demand in the short-run.

Our further investigation whether domestic gasoline or petroleum production could substitute for import. Even though commercial gasoline production could substantially reduce the dependence of Viet Nam on foreign sources in the long-run, the real answer remains an empirical and policy issue. Nonetheless, we do not expect to see a dominating effect of domestic oil production over the other determinants in our model. Our estimates show via models (3) and (4) in Table 5, and Table 6 shows domestic gasoline production could potentially substitute for gasoline imports in both the short and long term. However, it is only significant if we account for all potential determinants of gasoline imports in both periods (model (3) in table 5 and table 6 ). The magnitude of the estimated coefficient in the short-run of -0.060 indicates that the effect of increased gasoline production is almost negligible and with the temporary effect in the short term. In the long-run, however, the effect is much stronger though still inelastic $(-0.079)$.

Finally, population growth could spur demand for petroleum products in Viet Nam. The annual growth rate in the population is only marginally significant (10\%) and positive in the short run. Perhaps, the urban growth rate could be a better variable than population growth. However, its inclusion in a series of trial models did not significantly improve the results, with population growth giving many credible estimates.

Table 3: Long-run elasticity

\begin{tabular}{|c|c|c|c|c|}
\hline \multicolumn{5}{|c|}{ Dependent variables: $\ln G M$} \\
\hline Models & (1) & $(2)$ & (3) & (4) \\
\hline \multirow[t]{2}{*}{$\mathrm{C}$} & -14.663 & -18.891 & -24.110 & -15.621 \\
\hline & $(-5.64)^{* * *}$ & $(-5.76) * * *$ & $(-5.67) * * *$ & $(-5.88) * * *$ \\
\hline \multirow[t]{2}{*}{$\mathrm{Ln} G P$} & -2.396 & -3.245 & -1.686 & -3.879 \\
\hline & $(-1.94)$ & $(-2.29)^{*}$ & $(-2.66) * *$ & $(-0.80)$ \\
\hline \multirow[t]{2}{*}{$\ln G D P$} & 3.406 & 5.156 & 5.657 & 3.046 \\
\hline & $(6.40)^{* * *}$ & $(8.71) * * *$ & $(7.65) * * *$ & $(3.56) * * *$ \\
\hline \multirow[t]{2}{*}{$\ln R E E R$} & & 7.582 & 7.366 & 7.457 \\
\hline & & $(2.59)^{* * *}$ & $(2.66) * *$ & $(2.59) * *$ \\
\hline \multirow[t]{2}{*}{$\ln G P r d$} & & & -0.079 & -0.994 \\
\hline & & & $(-1.79)$ & $(-1.36)$ \\
\hline \multirow[t]{2}{*}{$P O P G$} & & 1.965 & & 1.788 \\
\hline & & $(1.17)$ & & $(-1.47)$ \\
\hline
\end{tabular}

Table 4: Short-run elasticity

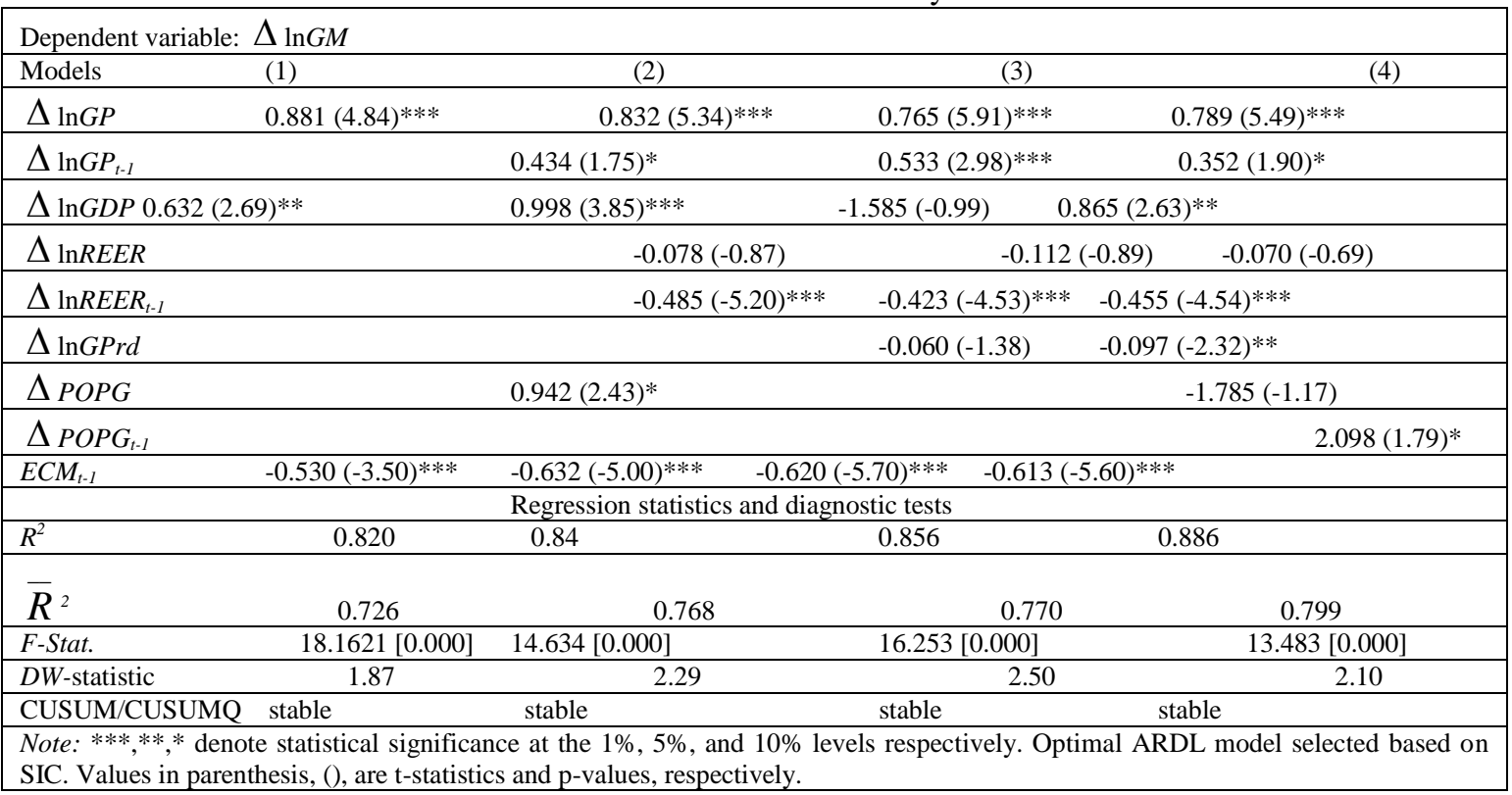




\section{Conclusion}

Overall, this is the first study that empirically estimates factors accounting for import demand for petroleum product gasoline. We have applied the ARDL co-integration approach by Pesaran et al. (2001) to test for the existence of long-run equilibrium relationship between the real import of gasoline and real gasoline price, real economic activity, a real effective exchange rate, domestic gasoline production and population growth. According to the confirmation of the long-run equilibrium existences, we isolated these effects by estimating the long-run and similar short-run models. Our results show that while import demand for gasoline is price inelastic in both the long and short run, the story is different for real economic activities while the price elasticity estimate is theoretically consistent in the long-run, the reverse found in the short-run. Specifically, an increase in real petroleum products price significantly stimulates gasoline import. The inelastic gasoline price elasticity implies the lack of diversified energy substitutes or alternatives.

Other interesting results show that demand for gasoline is income inelastic in the short-run but highly income elastic in the long-run even though significantly positive in all cases considered. Furthermore, the real effective exchange rate is a significant driver of gasoline import demand in both long and short run periods. Our results suggest that Viet Nam could reduce its heavy petroleum products import bill if we increase domestic production. With output potential of the Dung Quat or Nghi Son projected to grow in the foreseeable future, the government should re-think its policy on exporting the entire lifted petroleum products outside of the shores of the nation.

\section{References}

[1]. Adeolu O. Adewuyi, 2016. Determinants of import demand for non-renewable energy (petroleum) products: Empirical evidence from Nigeria. Energy Policy, Volume 95, August 2016, Pages 73-93

[2]. Stephanie Searle, Chris Malins., 2016. Case study: Refineries in Vietnam. International Council on Clean Transportation George Marbuah, 2016. Understanding crude oil import demand behaviour in Ghana. MPRA Paper No. 60436, posted 7 December 2014 10:40 UTC

[3]. International Energy Agency (IEA). 2016. Oil Market Report. September 2016.

[4]. Available online: http://omrpublic.iea.org/Trading Economics. 2016. Vietnam. September 2016.

[5]. Available online: http://www.tradingeconomics.com/vietnam/wages The World Bank. 2016. Oil Market Report. September 2016

[6]. Available online: http://data.worldbank.org/indicator/TX.VAL.MRCH.CD.WT?locations=VN

[7]. Seydina Ousmane Sene, 2012. Estimating the demand for gasoline in developing countries: Senegal. Energy Economics Volume 34, Issue 1, January 2012, Pages 189-194

[8]. Hye, Q.M.A. (2012). Exports, imports and economic growth in China: an ARDL analysis. Journal of Chinese Economic and Foreign Trade Studies, Vol.5 No.1, pp. 42-55

[9]. C-Y-C.Lin. 2011. Estimating supply and demand in the world oil market. The International Research Center, The Journal of Energy and Development, Vol. 34, Nos. 1 and 2 Askari, H., Krichene, N., 2010. An oil demand and supply model are incorporating monetary policy. Energy 35, 2013

[10]. Hillard G.Hunting, July 2009. Short and Long-run Adjustments in US Petroleum Consumption. Energy Economics Ghosh, S., 2009. Import demand for crude oil and economic growth: evidence from India. Energy Policy 37, 699-702

[11]. Oludele A. Akinboade, Emmanuel Ziramba, Wolassa L. Kumo, 2008. The demand for gasoline in South Africa: An empirica analysis using co-integration techniques. Energy Economics Volume 30, Issue 6, November 2008, Pages 3222-3229

[12]. Awokuse, T.O.(2007). Causality between exports, imports, and economic growth: evidence from transition economies. Economics Letters, Vol.94 no.3, pp.389-395

[13]. Ferda Halicioglu, 2007. The demand for new housing in Turkey: an application of ARDL model. Global Business and Economics Review, Vol.9, No.1

[14]. Altinay, G., 2007. Short-run and long-run elasticities of import demand for crude oil in Turkey. Energy Policy 35. 5829-5835

[15]. Ouattara, B., (2004). Foreign Aid and Fiscal Policy in Senegal. The Mimeo University of Manchester.

[16]. Pesaran, M. H., Shin, Y. and Smith, R. J., 2001. Bounds testing approaches to the analysis of level relationships. Journal of Applied Econometrics, 16, 289-326

[17]. Alves, D.C.O., Bueno, R.D.L.D.S., 2003. Short-run, long-run and cross elasticities of gasoline demand in Brazil. Energy Economics 25. 191-199

[18]. Asche, F., Gjolberg, O., Volker, T., 2003. Price relationships in petroleum markets: an analysis of crude oil and refined product prices., Energy Econ, 2003.25, 289-301

[19]. Pesaran, M. H. and Y. Shin, 1999. An autoregressive distributed lag modeling approach to co-integration analysis. Chapter 11 in S Strom (ed.). Econometrics and Economic Theory in the 20th Century: The Ragnar Frisch Centennial Symposium. Cambridge University Press, Cambridge

[20]. Pesaran, M. H. and R. P. Smith, 1998. Structural analysis of cointegrating VARs. Journal of Economic Surveys, 12, 471-505 Toda, H. Y and T. Yamamoto (1995). Statistical inferences in vector autoregressions with possibly integrated processes. Journal of Econometrics, 66, 225-250

[21]. Brown RL, Durbin J, Evans JM (1975). Techniques for Testing the Constancy of Regression Relationships over Time. Journal of the Royal Statistical Society B, 37, 149-163

[22]. Ouattara, B., (2004). "Foreign Aid and Fiscal Policy in Senegal." Mimeo University of Manchester.

[23]. Ouattara, B., (2004). "Foreign Aid and Fiscal Policy in Senegal." Mimeo University of Manchester. 